Working Paper No. 33

$$
\begin{aligned}
& R \\
& \text { UM } \\
& 631.7 .1 \\
& \text { G19. } \\
& \text { PUR } \\
& H 16109
\end{aligned}
$$

\title{
LIFT IRRIGATION IN WEST AFRICA: \\ CHALLENGES FOR \\ SUSTAINABLE LOCAL MANAGEMENT
}

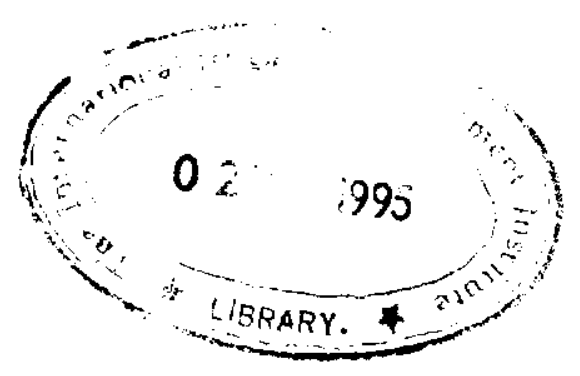

\author{
David R. Purkey \\ and \\ Douglas Vermillion
}

H 16109

$c_{2}$

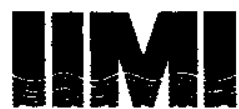

INTERNATIONAL IRRIGATION MANAGEMENT INSTITUTE 
Purkey, D. R.; Vermillion, D. 1995. Lift irrigation in West Africa: Challenges for sustainable local management. Colombo, Sri Lanka: International Irrigation Management Institute (IIMI). ix, 51p. (IIMI working paper no.33).

/ irrigation management / water resources / low lift imigation / social aspects / economic aspects / technology / grounctwater development / surface water / environment / sustainability / policy / climate / West Africa / Burkina Faso / Cameroon / Chad / Gambia / Mali / Mauritania / Niger / Nigeria / Senegal /

DDC: 631.7

ISBN: 92-9090-314-7

IIMI's Working Paper series is intended to stimulate discussion among people interested in aspects of irrigation management. These papers make available the results of recent or ongoing research, and the informed opinions of IIMI staff members and collaborators, as early as possible. The views expressed are, therefore, those of the authors and do not (at this stage) necessarily represent the consensus of IIMI or its partners. IIMI will welcome comments on this paper, which should be sent either to IIMI or to the authors at the following address:

Information Office

International Irrigation Management Institute

P.O. Box 2075

Colombo, Sri Lanka

(C) IIMI, 1995

All rights reserved. 


\section{Contents}

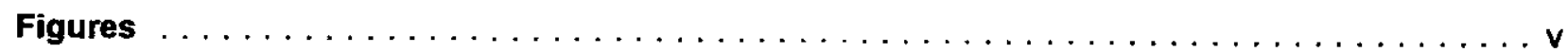

Tables $\ldots \ldots \ldots \ldots \ldots \ldots \ldots \ldots \ldots \ldots \ldots \ldots \ldots \ldots \ldots \ldots \ldots \ldots$ vii

Preface $\ldots \ldots \ldots \ldots \ldots \ldots \ldots \ldots \ldots \ldots \ldots \ldots \ldots \ldots \ldots \ldots \ldots \ldots \ldots$

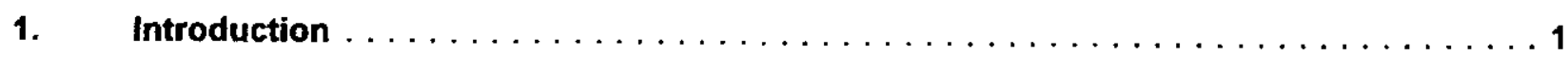

2. Objectives $\ldots \ldots \ldots \ldots \ldots \ldots \ldots \ldots \ldots \ldots \ldots \ldots \ldots \ldots \ldots \ldots \ldots \ldots$

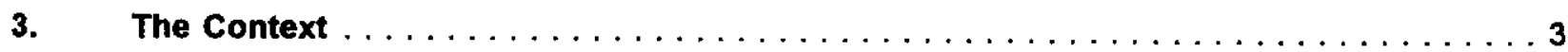

3.1. Geophysical and Climatic Context $\ldots \ldots \ldots \ldots \ldots \ldots \ldots \ldots \ldots \ldots$

3.2. Water Resources and Irrigation $\ldots \ldots \ldots \ldots \ldots \ldots \ldots \ldots \ldots \ldots \ldots \ldots$

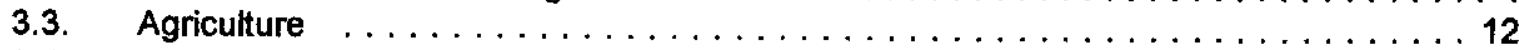

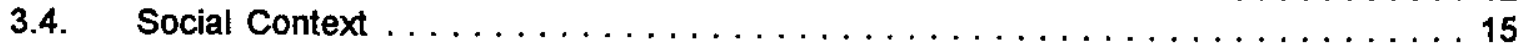

4. Evolution of Lift Irrigation in West Africa $\ldots \ldots \ldots \ldots \ldots \ldots \ldots \ldots \ldots \ldots \ldots \ldots$

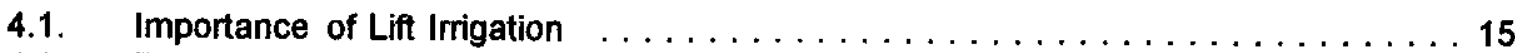

4.2. Traditional and Modern Lift Irrigation Technologies $\ldots \ldots \ldots \ldots \ldots \ldots \ldots \ldots$

5. Groundwater Lift Irrigation in West Africa $\ldots \ldots \ldots \ldots \ldots \ldots \ldots \ldots \ldots \ldots \ldots \ldots$

5.1. Local Technologies for Groundwater Development $\ldots \ldots \ldots \ldots \ldots \ldots \ldots \ldots$

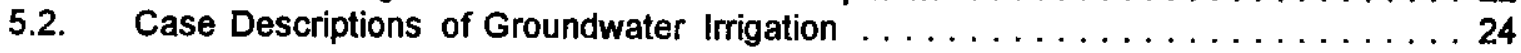

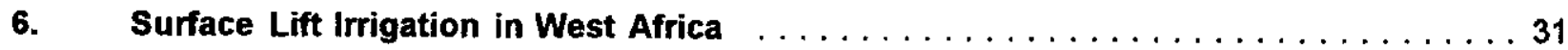

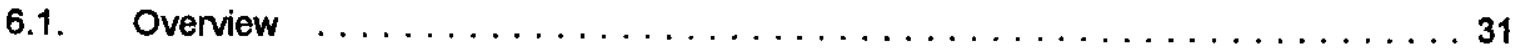

6.2. Case Descriptions of Surface Lift Irrigation $\ldots \ldots \ldots \ldots \ldots \ldots \ldots \ldots \ldots \ldots \ldots$

7. Research and Development Priorities for Lift Irrigation in West Africa $\ldots \ldots \ldots 41$

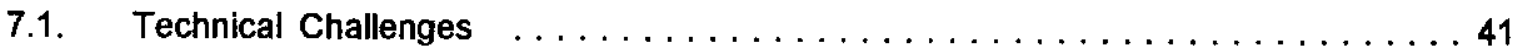

7.2. Agricultural and Economic Challenges $\ldots \ldots \ldots \ldots \ldots \ldots \ldots \ldots \ldots \ldots \ldots$

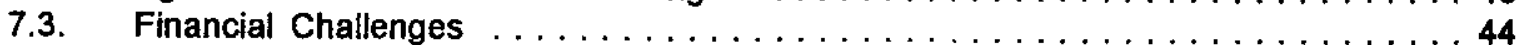

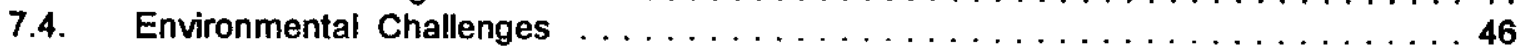

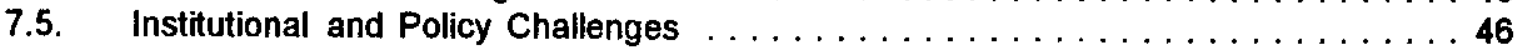

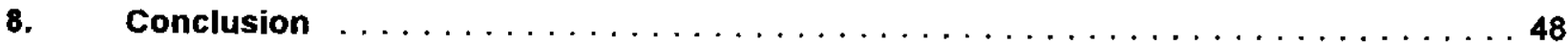

References. . . . . . . . . . . . . . . . . . . . . . 49 


\section{Figures}

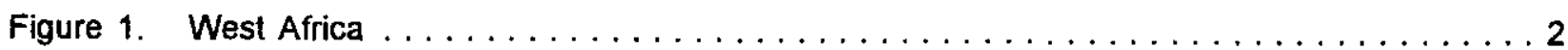

Figure 2. The "shaduf"counterpoise lift, West Africa $\ldots \ldots \ldots \ldots \ldots \ldots \ldots \ldots$

Figure 3. Shaduf lifting water out of stream, Northern Nigeria $\ldots \ldots \ldots \ldots \ldots$

Figure 4. Using rope-and-bag to lift water from a dug-well, West Africa $\ldots \ldots \ldots \ldots$

Figure 5. Portable axial flow pump, example of one type of surface

lift irrigation technology 


\section{Tables}

Table 1. Typical climatic data for countries in the study area $\ldots \ldots \ldots \ldots \ldots \ldots$

Table 2. Comparison of annual precipitation and potential evaporation for selected Sahelian sites $\ldots \ldots \ldots \ldots \ldots \ldots \ldots \ldots$

Table 3. Water resources and irrigation potential in sample West African countries . . . . . 6

Table 4. Irrigated area, area developed and cropping intensity in selected West African

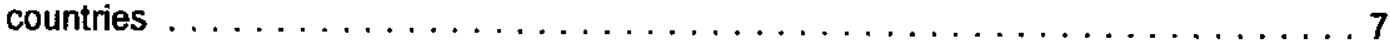

Table 5. Relative importance of modern and traditional irrigation in the nine countries of

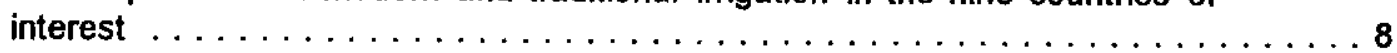

Table 6. Aquifer yields for selected hydrogeologic formations in West Africa $\ldots \ldots \ldots \ldots 11$

Table 7. Crop areas as percent of total irrigated agricultural land and agricultural use of irrigated lands in selected West African Countries . . . . . . . . . . 13

Table 8. Yields of main irrigated crops $(t / h a)$ in selected West African countries $\ldots \ldots \ldots \ldots 14$

Table 9. Physical characteristics of selected water-lifting devices $\ldots \ldots \ldots \ldots \ldots \ldots$ 


\section{Preface}

Lift irrigation in West Africa has indigenous roots with traditional technologies and management arrangements. Farmers in the region often invest in modern, pump lift technologies through indigenous credit arrangements. Lift irrigation, either traditional or modern, is generally cheaper to develop than surface irrigation (estimates are that it is often between 10 and 30 percent of the cost), its benefits can be derived more quickly and farmers have much more control over the timing and efficiency of the service. Furthermore, it does not generally require as much government bureaucracy to support its development or management.

While most agriculture in West Africa is rain-fed, the fragility of the agricultural and economic environment motivates farmers to seek to diversify their production and marketing opportunities. Lift irrigation provides such an opportunity. Nevertheless the relatively high development costs and extreme poverty in the region require a careful mix of government subsidies and support services and local financial and organizational investments if lift irrigation is to be both worthwhile and sustainable in the region.

This working paper provides an overview of the status, context and types of lift irrigation technologies and uses in West Africa. Brief case study descriptions provide insights into local interactions between physio-technical, environmental and agro-economic aspects of managing lift irrigation in the region. Research and development priorities are suggested.

Information on Niger and general comments from Kurt Lonsway of IIMI's Niger office have been incorporated into this working paper. 


\title{
Lift Irrigation in West Africa: Challenges for Sustainable Local Management
}

\author{
David R. Purkey and Douglas Vermillion ${ }^{1}$
}

\section{Introduction}

Irrigation development in Africa has progressed at a slower pace than in other parts of the developing world. Food security, in most parts of the continent, has traditionally been pursued through rain-fed farming systems. In West Africa, these systems are generally extensive in nature with large expanses of land planted to cereals, such as millet and sorghum, using very few inputs. In recent years, two factors have put increasing pressure on these cropping systems. First, rapid population growth of 3.2 percent per annum (FAO 1986a) increasingly limits the amount of arable land available per family for extensive subsistence agriculture. Second, recent patterns of subpar rainfall have led to repeated crop failures. These two factors alone have led to an increased interest in irrigated agriculture in the region.

Irrigated agricultural systems have existed in West Africa for generations, although they have been viewed primarily as income generating activities which supplement rain-fed agriculture. Now they are increasingly viewed, by farmers and policymakers alike, as a crucial element of a diversified rural economic survival strategy. This change in perception has prompted several recent efforts to improve the efficiency of irrigation systems and to expand the surface area under irrigation. Lift irrigation, exploiting both surface water and groundwater, has been a major focus of these efforts. In fact, lift irrigation, which includes many farmer-managed irrigation systems and systems where farmers participate in management, is increasingly preferred over the development of large-scale, strictly agencymanaged, water impoundment and diversion systems.

This report examines some of the salient features of lift irrigation in West Africa. It is based on the experience of the authors and on evidence available in the development literature. The document is by no means an exhaustive treatment of the subject. Hopefully, however, it will offer some insight into an emerging development strategy which offers potential to improve the quality of life of rural Africans. Both the successes and shortcomings of lift irrigation system development will be considered in the hope of providing useful recommendations for future initiatives. A special emphasis will be placed on strategies to strengthen the role of local farmers in lift irrigation management.

\section{Objectives}

The chief objectives of this report are (1) to characterize the current status of lift irrigation management and performance in West Africa, (2) to identify key stresses or constraints upon the sustainability and expansion of lift irrigation in West Africa, and (3) to suggest priorities for research and development action to ensure the viability of locally managed lift irrigation in West Africa. This will be accomplished by examining the technical and institutional arrangements which exist in the region. A set of case descriptions of various lift irrigation sites in the region, which reveal the variety of institutional and social arrangements in place to manage lift irrigation, will guide the examination.

\footnotetext{
'David Purkey is a Ph.D. student in irrigation engineering at the University of California at Davis, USA. Douglas Vermillion is a rural sociologist at IIMI.
} 


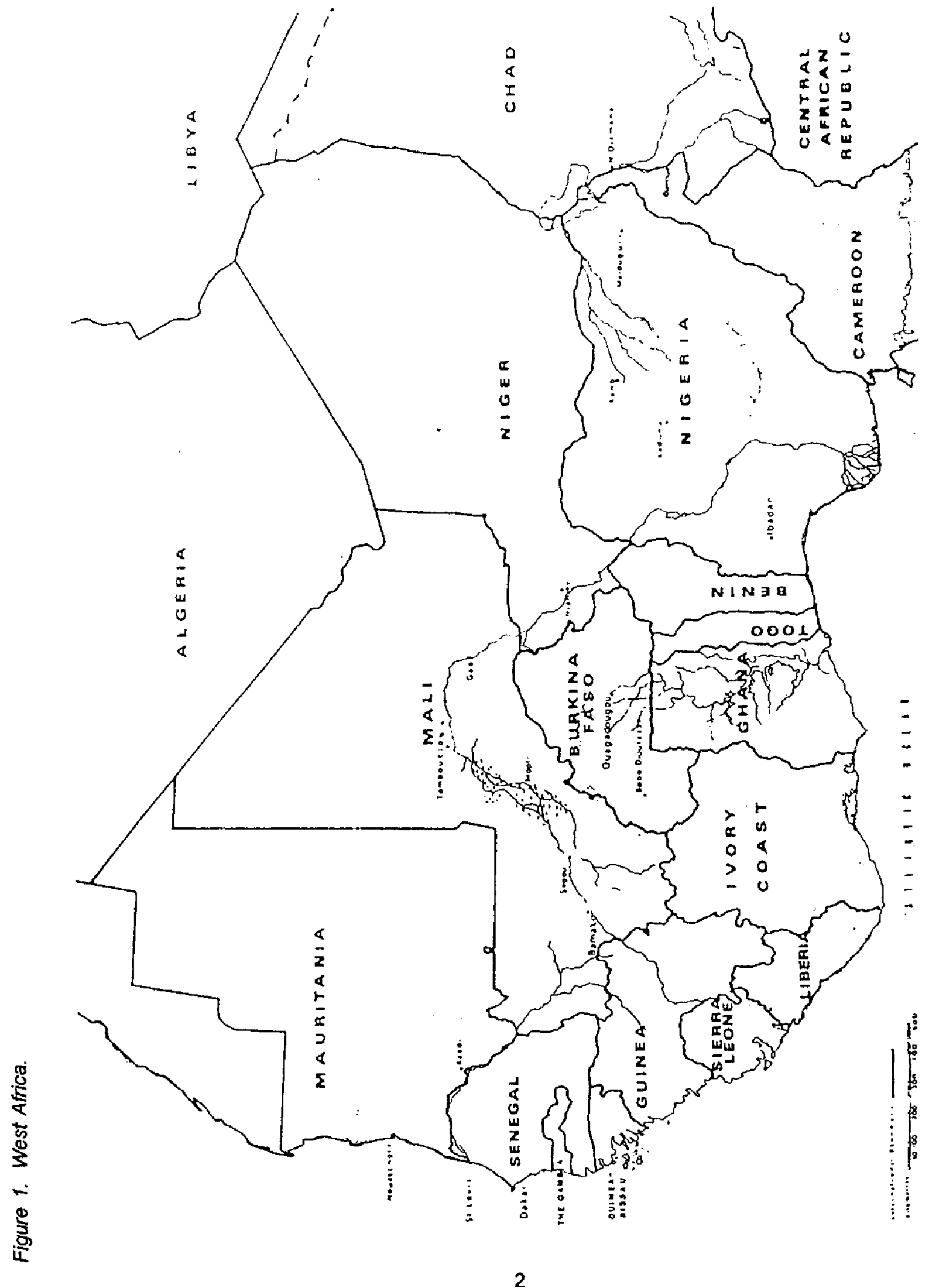




\section{The Context}

\subsection{Geophysical and Climatic Context}

In the broadest sense, West Africa can be defined as the great lobe of the continent formed by the westward turn of the Atlantic coastline in Cameroon (Figure 1). Extrapolating the north-south oriented Atlantic coastline below Cameroon, north to the Mediterranean Sea, yields a strictly Cartesian demarcation of the region. In point of fact, this is a good first estimate.

Nonetheless, several geographical features of the region are helpful in refining this demarcation. The most significant of these is the Sahara Desert in the north. Cutting across the western lobe from Mauritania in the west to Chad in the east, the desert forms a formidable boundary between the nations to the south, and the Mahgreb countries along the Mediterranean Sea in the north. Even today, desert crossings are the domain of nomads and adventurers. As such, it is difficult to lump the Mahgreb and West Africa south of the Sahara together for any study, including one of lift irrigation.

The second geographic feature of importance in defining West Africa for this study is the coastal Guinean ecological zone. This zone, which follows the coastline from Cameroon to Guinea, extends inland for several hundred kilometers in places. It is characterized by heavy rainfall and tropical vegetation. Irrigation, even at the smallest scale, is not common.

Positioned between the Sahara Desert and the coastal tropical belt lie the Sahel and the Sudanese zones which extend across the continent from east to west. In this zone rain-fed agricultural systems are predominant. Nonetheless, a significant amount of irrigation is practiced, though largely to supplement farmer livelihood strategies. These systems are either traditional, having been in place often for generations or modem, having been introduced in the past several decades. The majority of them can be classified as lift irrigation systems. It is in this region that the greatest variety of irrigation systems exist and where there is the most potential for irrigated agriculture to make a positive contribution to rural development.

Following these broad boundaries, and selecting countries with the significant amounts of irrigated land or systems, we have included the countries of Burkina Faso, Cameroon, Chad, the Gambia, Mali, Mauritania, Niger, Nigeria and Senegal in this regional study (Figure 1). Several small, tropical, high rainfall countries, such as the Ivory Coast, Ghana, Togo, Benin, Sierra Leone and Guinea Bissau are not considered herein because of the limited extent of irrigation found in these countries.

In this sub-Saharan, Sudano-Sahelian zone, day-time temperatures can reach $30^{\circ} \mathrm{C}$ and $40^{\circ} \mathrm{C}$ and night-time temperature $20^{\circ} \mathrm{C}$ and below. A single rainy season generally spans about four months, with the rain-fed growing season in the area ranging from 60 to 140 days. The mean annual rainfall varies dramatically, often significantly less than $100 \mathrm{~mm}$ in places bordering the Sahara to above $1,700 \mathrm{~mm}$ in parts of Cameroon and Nigeria. Perhaps more difficult for farmers to cope with than consistently low rainfall is the erratic and uncertain temporal patterns of rainfall both between years and throughout the year. Often, a large percentage of the annual rainfall occurs during a few sporadic days of heavy rains and can result in serious erosion and siltation. These events can be followed by weeks, even months, of drought.

Table 1 presents some typical values of climatic extremes for the countries in West Africa. The data reveal the large variability in climatic extremes both within individual countries and across the region of interest. These extremes certainly influence the practice of irrigated agriculture. In addition, however, they also influence the inclination of farmers to undertake such an enterprise. It is not a gross oversimplification to claim that in areas of higher rainfall, where rain-fed agriculture is increasingly viable, farmers are less inclined to invest in irrigation. Irrigated agriculture becomes an increasingly important element of the rural economic strategy where rain-fed agriculture is marginal. 
Table 1. Typical climatic data for countries in the study area.

\begin{tabular}{|c|c|c|c|c|c|}
\hline Country & $\begin{array}{l}\text { Maximum } \\
\text { temperature } \\
\left({ }^{\circ} \mathrm{C}\right)\end{array}$ & $\begin{array}{l}\text { Minimum } \\
\text { temperature } \\
\left({ }^{\circ} \mathrm{C}\right)\end{array}$ & $\begin{array}{l}\text { Maximum } \\
\text { precipitation } \\
(\mathrm{mm} / \mathrm{yr})\end{array}$ & $\begin{array}{l}\text { Minimum } \\
\text { precipitation } \\
(\mathrm{mm} / \mathrm{yr})\end{array}$ & $\underset{(\mathrm{mm} / \mathrm{yr})}{\mathrm{ETP}}$ \\
\hline $\begin{array}{l}\text { Burkina } \\
\text { Faso }\end{array}$ & 45 & 7 & - & - & 1,750 \\
\hline Cameroon & 45 & 11 & 4,000 & 500 & - \\
\hline Chad & 40 & 13 & 1,400 & 200 & 2,100 \\
\hline Gambia & - & - & 1,200 & 900 & 2,250 \\
\hline Mali & - & - & 1,300 & $<200$ & - \\
\hline Mauritania & - & - & 600 & $<200$ & - \\
\hline Niger & - & - & 100 & 400 & - \\
\hline Nigeria & - & - & - & - & - \\
\hline Senegal & 37 & 15 & 1,500 & 350 & 1,200 \\
\hline
\end{tabular}

Source: UN 1988.

This trend is explained by data on the relative magnitude of annual precipitation and potential evapotranspiration. Table 2 compares these values for three sites in the arid Sahelian portion of the region. Here, precipitation can satisfy only a small percentage of the potential evapotranspiration. Under these conditions non-livestock related agricultural endeavors will require irrigation. As these are annual data, they lump the precipitation/ETP ratios from the wet and dry months. In some parts of West Africa, such as Ngouri, Chad, however, it has been found that during dry years the precipitation/ETP ratio can be less than unity every month of the year (ORT 1989). This includes the "rainy" months of July and August.

\subsection{Water Resources and Irrigation}

Table 3 displays country-averaged data on amount of water resources available from rainfall, groundwater, surface water and the total, by country in West Africa. The data reveal how climatic variations influence hydrologic conditions across the region. Nigeria and Cameroon dominate the region 
Table 2. Comparison of annual precipitation and potential evaporation for selected Sahelian sites.

\begin{tabular}{|l|c|c|c|}
\hline \multicolumn{1}{|c|}{ Site } & $\begin{array}{c}\text { Precipitation } \\
\text { (mm/year) }\end{array}$ & $\begin{array}{c}\text { ETP } \\
\text { (mm/year) }\end{array}$ & Precipitation/ETP \\
\hline Moudjeria, Mauritania & 170 & 1,870 & 0.03 \\
\hline Nouadhibou, Mauritania & 40 & 1,160 & 0.03 \\
\hline Kayes, Mali & 740 & 1,870 & 0.30 \\
\hline
\end{tabular}

Source: UN 1988.

in water availability and average rainfall, lying partially in the humid tropics. Considerable variation exists in average rainfall in West Africa since the region lies in a transition zone between the Sahara to the north and the humid tropics to the south.

Table 4 presents data on area irrigated relative to the potential area for selected West African countries. This indicates that most countries in the region have achieved less than 30 percent of their estimated potential irrigable area. The highest, Chad, has achieved 30 percent of its potential and the lowest, Burkina Faso, has achieved only 13 percent of its potential. Data for Nigeria were not included, as the country is not part of the organization which published these data. Table 4 also shows the annual rates of development of agency-directed irrigated areas for the period 1979 to 1989 . Most countries show an increase in agency-directed irrigated area at an average rate of several hundred hectares per year. Senegal had the highest rate of increase, which was 1,250 ha per year while Gambia showed a decrease during the period.

Many of the agency-directed systems fall under the rubric of "modern" irrigation, which tend to rely on full water control in order to provide water to crops. This is in contrast to "traditional" irrigation which functions with less physical control of water (FAO 1986a). Based on these loose definitions, the relative importance of modern and traditional irrigation in the countries of interest has been tabulated in Table 5. The data reveal how important the less-than-full water control systems, many of which are lift irrigation systems, are to irrigation in the region.

These data can be further analyzed to approximate the importance of traditional irrigation in human terms. Assuming that one family of six individuals can farm approximately one hectare under traditional irrigation, approximately 6.5 million people in the region depend on these systems for some portion of their livelihoods. In contrast, modern irrigation, with its higher level of water control would allow the same family to farm approximately 2 hectares (ha). This translates to approximately 700,000 people in West Africa who secure a portion of their livelihood through modern irrigation. These figures offer very striking evidence of the importance of traditional, generally farmer-managed, irrigation in the 9 countries of interest.

Given the scarcity of published data for the region, it is difficult to state the exact amount of lift irrigation which exists in West Africa. A cursory inventory of irrigation in the region (FAO 1986a), however, offers a glimpse of how important lift irrigation is. The amounts of inventoried land under irrigation via water diversion and pumping in selected countries are: 
* Burkina Faso, 2,000 ha diversion, 6,700 ha pumping;

* Mali, 107,000 ha diversion, 24,460 ha pumping;

* Mauritania, 6,900 ha pumping;

* Niger, 2,719 ha diversion, 11,802 pumping;

* Nigeria, 17,300 ha diversion, 805,000 pumping; and

* Senegal, 3,200 ha diversion, 16,800 pumping.

Table 3. Water resources and irrigation potential in sample West African countries.

\begin{tabular}{|c|c|c|c|c|c|}
\hline Country & $\begin{array}{l}\text { Area } \\
\mathrm{km}^{2}\end{array}$ & $\begin{array}{c}\text { Average } \\
\text { rainfall } \\
\mathrm{mm}\end{array}$ & $\begin{array}{c}\text { Ground- } \\
\text { water } \\
\text { resources } \\
\mathrm{km}^{3}\end{array}$ & $\begin{array}{c}\text { Surface } \\
\text { water } \\
\text { resource } \\
\mathrm{km}^{3}\end{array}$ & $\begin{array}{c}\text { Total water } \\
\text { resources } \\
\text { km }^{3}\end{array}$ \\
\hline Burkina Faso & 274,201 & 898 & 4,324 & 22,829 & 27,153 \\
\hline Cameroon & 475,380 & 1,717 & 15,403 & 117,327 & 132,730 \\
\hline Chad & $1,283,942$ & 381 & 46,696 & 36,362 & 83,058 \\
\hline Gambia & 11,303 & 938 & 1,285 & 1,062 & 2,347 \\
\hline Mali & $1,240,115$ & 365 & 8,931 & 31,106 & 40,036 \\
\hline Mauritania & $1,030,741$ & 119 & 2,040 & 0 & 2,040 \\
\hline Niger & $1,266,995$ & 187 & 10,878 & 2,163 & 13,042 \\
\hline Nigeria & 923,744 & 1,265 & 49,354 & 145,358 & 194,712 \\
\hline Senegal & 196,200 & 777 & 14,016 & 11,450 & 25,466 \\
\hline Total & $5,778,877$ & & 103,573 & 222,299 & 325,872 \\
\hline
\end{tabular}

Source: FAO 1987. 


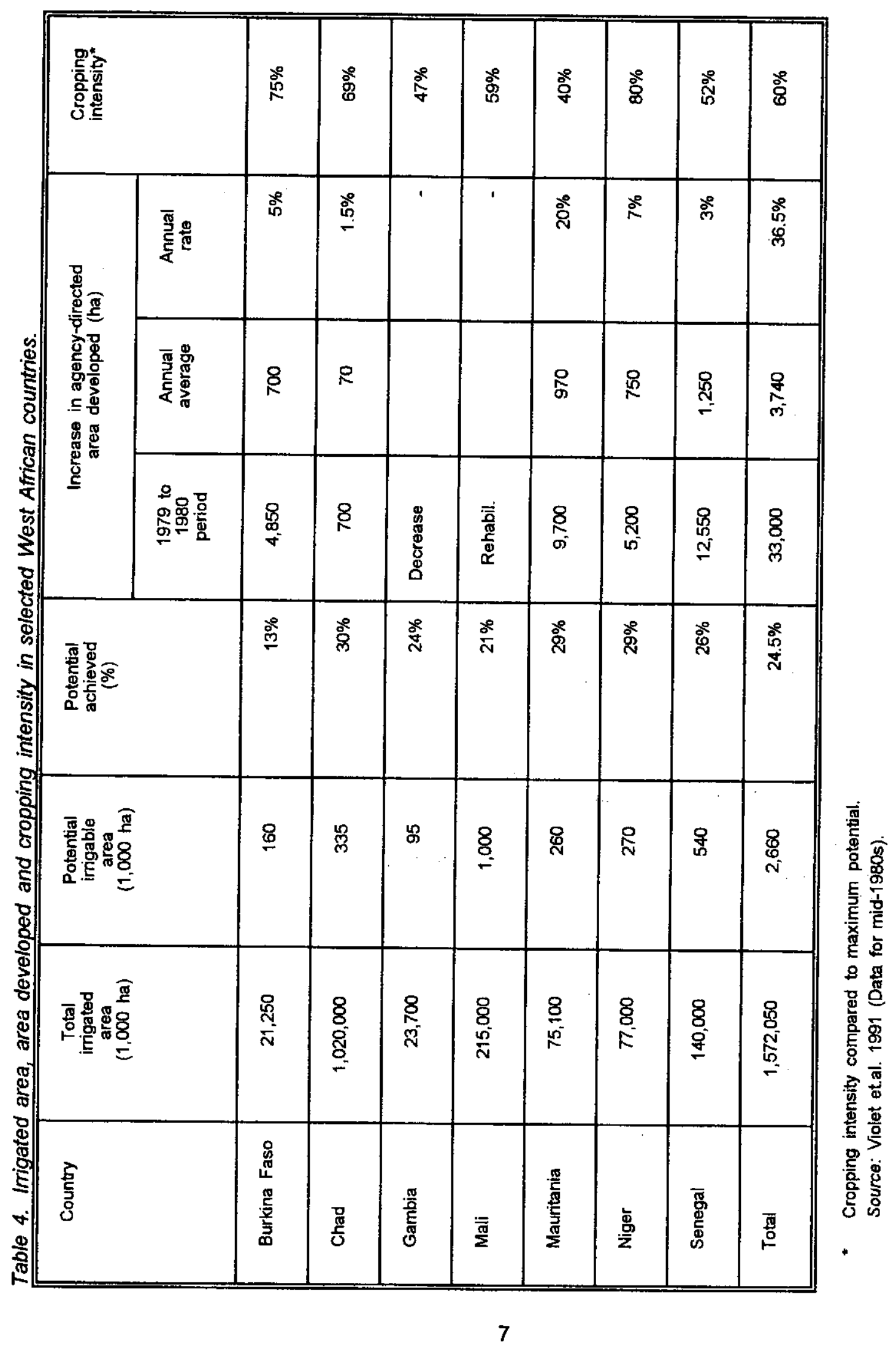


Table 5. Relative importance of modern and traditional imigation in the nine countries of interest.

\begin{tabular}{|c|c|c|c|}
\hline Country & $\begin{array}{c}\text { Modern } \\
(1,000 \text { ha })\end{array}$ & $\begin{array}{l}\text { Traditional } \\
(1,000 \text { ha) }\end{array}$ & $\begin{array}{l}\text { Modern/ } \\
\text { Traditional }\end{array}$ \\
\hline Burkina Faso & 9 & 20 & 0.45 \\
\hline Cameroon & 11 & 9 & 1.22 \\
\hline Chad & 10 & 40 & 0.25 \\
\hline Gambia & 6 & 20 & 0.30 \\
\hline Mali & 100 & 60 & 1.67 \\
\hline Mauritania & 3 & 20 & 0.15 \\
\hline Niger & 10 & 20 & 0.50 \\
\hline Nigeria & 50 & 800 & 0.06 \\
\hline Senegal & 30 & 70 & 0.43 \\
\hline Total & 229 & 1,059 & 0.22 \\
\hline
\end{tabular}

Source: FAO 1986a.

These data are not exhaustive. In addition, they do not include flood irrigation which takes advantage of the natural rise and fall of the regions' surface water bodies. Nonetheless, they serve to reinforce the conclusion that lift irrigation is a major component of the total amount of irrigation in the region. These systems certainly merit closer inspection, particularly regarding the role that the local management can play in their sustainable development and operation.

In contrast to Asia, in West Africa there has been relatively little development of large-scale, agencymanaged water impoundment and diversion structures. Those that have been developed are generally perceived to have been less than successful. In fact, many believe that it is difficult to point to any large agricultural project which has made a dent in the current food crisis (ENR News 1985). As a result, a shift in approach is underway towards small-scale schemes which fit appropriate elements of modern irrigation development with traditional agricultural practices, including the integration of farmers into irrigation management arrangements.

A wide variety of irrigation systems found in the region can be classified under the general heading of lift irrigation. These range in sophistication from a farmer using a bucket to draw water from a shallow, 
hand-dug well to pump stations of several hundred horsepower pumping water from a major river for several hundred farmers. There is much diversity among lift irrigation systems in the region.

The two primary types of lift irrigation in West Africa are: 1) groundwater lift irrigation and 2) surface lift irrigation systems. Further sub-divisions of these two broad categories are found, respectively, in Section 5 and 6 below. Groundwater irrigation is defined as irrigation which relies on some mechanical system or device to lift water from an aquifer developed using a physical structure. Surface lift irrigation, on the other hand, is defined as irrigation which relies on some mechanical system or device to lift water from a surface water body.

This shift has led to increased interest in small-scale irrigation projects, many of which propose development of lift irrigation systems. Small-scale irrigation is defined as irrigation of small plots of land which calls upon technologies whose operation and maintenance can be carried out by the farmers themselves (CTA 1991). This definition does not apply to all lift irrigation systems in West Africa and it is not applicable to any of the large-scale water impoundment and diversion systems.

In order to properly assess the current and potential importance of lift irrigation in West Africa, it is first necessary to characterize groundwater and river basin resources. Figure 2 presents the basic configuration of the principal watersheds in the region as well as the distribution of the major hydrogeologic units.

In terms of using surface water for lift irrigation, 3 watersheds are of particular importance to West Africa. These are: the Senegal River Basin in the west which is of particular interest to Senegal and Mauritania; the massive Niger River Basin which covers large parts of Mali, Burkina Faso, Niger and Nigeria; and the Lake Chad Basin in the east which contains surface water of importance to Chad and Cameroon. Each watershed contains several rivers with year-round flow. Lift irrigation along these rivers occurs in a myriad of forms. One of the most striking is the small market gardening which has sprung up in the vicinity of riverfront urban centers. Near Bamako and Niamey on the Niger, and N'Djamena on the Chari, farmers lift water from the rivers using any number of methods. These neatly tended farms have, almost exclusively, sprung up through individual farmer initiative. Other lift irrigation systems, such as the Office National des Aménagements Hydro-Agricoles (ONAHA) systems in Niger, rely on large pumping plants to provide water to multiple farm units.

One element of the hydrology of most West African rivers favors the more flexible farmer-managed approach. These rives are characterized by temporarily varying hydrographs with high flow in the wet season and low flow during the dry months. This feature, combined with the minimal relief typical of much of West Africa, leads to extensive flooding. In the Senegal River Valley, some $5,000 \mathrm{~km}^{2}$ of floodplain are inundated at high flow, while at low flow the figure drops to $500 \mathrm{~km}^{2}$. Approximately 6,000 $\mathrm{km}^{2}$ of fringe floodplain is flooded when the Niger River is at peak flow, the figure dropping by half in the dry season. Most dramatic, in the Logone-Chari floodplain south of Lake Chad, peak flooding covers some $90,000 \mathrm{~km}^{2}$, of which only 7 percent remains inundated at low water (Adams 1992). in the absence of major investments in flood control structures, these fluctuations make it difficult to find sites where the large pumping stations required by agency-managed surface lift irrigation systems will be simultaneously above and adjacent to water.

As seen in Figure 1, vast areas of West Africa lie far removed from the perennial streams of the major watersheds. In these areas, lift irrigation relies on the development of groundwater for irrigation. The characteristics of the region's aquifers strongly influence the development of locally managed, groundwater lift irrigation. There are 4 principle types of aquifers in West Africa:

* Consolidated sediments such as sandstone, schist, and shale which underlie the vast majority of the desert and savanna zones of Niger, Burkina Faso, Mati, and northem Ghana. 
* Weathered and fractured crystalline basement rock which covers portions of Burkina Faso, Ivory Coast, Ghana, Togo, Benin, and Nigeria.

* Unconsolidated cretaceous sediments and tertiary sands and gravels of the continental shield.

* Alluvial deposits associated with the principal river basins, coastal plains, and the Lake Chad Basin (des Bouvrie 1973).

These aquifers are by no means uniform in their hydraulic properties when considered on a regional scale. Nonetheless some general statements regarding their potential to support the development of groundwater irrigation can be made.

The second type of aquifer, weathered and fractured crystalline rock, has a fair potential to yield sufficient groundwater for irrigation development. This is due largely to the presence of a decomposed upper margin with high secondary porosities. Very often these margins are found close enough to the surface to justify their development, particularly when they lie below valleys where ephemeral surface flow concentrates and infiltrates. The typical profile in these regions has lateritic soils overlying clayey sand which grade into coarse sands. The zone of alteration lies between these sediments and the unaltered crystalline rock below and is located between 2 and $100 \mathrm{~m}$ below the ground surface. The decomposition of the crystalline rock is associated with paleohumidity, and thus, even in dry areas, these aquifers exist.

A large part of water contained in sediment associated with the continental shield (aquifer types 1 and 3) is probably fossil or semifossil in origin. These waters likely found their way to these formation during earlier periods of high precipitation (Quaternary). Significant development of these aquifers would likely exceed the recharge capacity and lead to aquifer dewatering. These aquifers are generally found at great depth, which also limits their usefulness for irrigation. In Niger, for example, geophysical surveys have found that they lie from several hundred to $800 \mathrm{~m}$ below the ground surface.

The final aquifer type, alluvial deposits, is extremely variable in West Africa. Some general comments can be made, however, regarding those associated with major West African watercourses. In many parts of the world, alluvial deposits include productive deposits of coarse sands and gravels. In general, coarse sediments are deposited by watercourses which drain zones where the material available for transport includes a large percentage of sand and gravel, and where flow velocities are high enough, as a result of steep topographic gradients, to entrain them (Freeze and Cherry 1979). Neither criteria is commonly met by West African rivers. Watercourse slopes are generally gentle, 0.25-0.5 $\mathrm{m} / \mathrm{km}$, and only rarely are extensive deposits of coarse sand and gravel common. River sediments are often fine or very fine which inhibits their ability to recharge and yield water under pumping. Yet, in places, these sediments do offer potential for irrigation development.

A second type of alluvial deposit is associated with zones of flash flooding common in Chad, Cameroon, southern Niger and northern Nigeria. These zones experience sudden heavy rainfall and concentrated runoff. Large quantities of coarse material are entrained by these floods and thus the zones are called "sand" rivers. As most of these rivers do not discharge into permanent water courses, the coarse materials are deposited in concentrated areas and the totality of runoff eventually infiltrates or evaporates. The aquifers in these zones, which are not deep, often contain significant quantities of water. The Bahr al-Gazal in central Chad and the Maradi Goulbi in southern Niger are good examples of this type of aquifer.

It must be kept in mind that aquifer properties are extremely variable, even for materials of similar origin. Local variabilities, such as the degree of weathering in igneous rocks or the clay content in sedimentary formations, can influence yields by orders of magnitude. To demonstrate this variability for 
the aquifer types described above, aquifer yields have been complied in Table 6 for several waterbearing units in West Africa. To put these figures in context one can assume a potential evapotranspiration rate of $10 \mathrm{~mm} / \mathrm{day}$. This is not unreasonable for the arid Sahelian regions of the region. If a farmer lifts water for 8 hours at a rate of $1.0 \mathrm{~m}^{3} / \mathrm{hr}, 8 \mathrm{~m}^{3}$ of water would be available for irrigation. If the farmer's irrigation system operates at 60 percent efficiency, this volume would permit the irrigation of approximately $500 \mathrm{~m}^{2}$ of land.

Clearly, most of the water-bearing units in the region have yields in excess of $1.0 \mathrm{~m}^{3} / \mathrm{hr}$. Thus, it seems that in much of the region irrigation is limited by a farmer's ability of lift water and not by attainable aquifer yields. If such irrigation is to be sustainable, however, care must be taken to assure that the amount of water withdrawn from the aquifer does not exceed the aquifer's rate of recharge. This is a function both of the rate at which farmers are extracting water and the number of farmers who are using the resource.

Making regional generalizations about groundwater quality is even more tenuous than speculating about aquifer hydraulic properties. Any groundwater irrigation development should include a detailed water quality investigation. This being said, two general comments can be made regarding groundwater quality in West Africa.

Table 6. Aquifer yields for selected hydrogeologic formations in West Africa.

\begin{tabular}{|c|c|c|}
\hline Material & Location & $\begin{array}{c}\text { Yield } \\
\left(\mathrm{m}^{3} / \mathrm{hr}\right)\end{array}$ \\
\hline Sandstone & $\begin{array}{l}\text { Cameroon } \\
\text { Senegal }\end{array}$ & $\begin{array}{r}10-20 \\
15-120\end{array}$ \\
\hline Limestone & $\begin{array}{l}\text { Mauritania } \\
\text { Senegal }\end{array}$ & $\begin{array}{l}0.1- \\
1 \\
4\end{array}$ \\
\hline Schist & $\begin{array}{c}\text { Mali } \\
\text { Mauritania }\end{array}$ & $20^{0.5}$ \\
\hline Gneiss & $\begin{array}{l}\text { Mauritania } \\
\text { Burkina Faso }\end{array}$ & $\begin{array}{r}1 \\
1-4\end{array}$ \\
\hline Granite & $\begin{array}{c}\text { Chad } \\
\text { Burkina Faso }\end{array}$ & $\begin{array}{r}2 \\
1-4\end{array}$ \\
\hline Continental shield & $\begin{array}{l}\text { Mauritania } \\
\text { Mali }\end{array}$ & $\begin{array}{r}1-4 \\
50-100\end{array}$ \\
\hline Aluvium & $\begin{array}{l}\text { Mauritania } \\
\text { Cameroon }\end{array}$ & $\begin{array}{r}10 \\
10-80\end{array}$ \\
\hline
\end{tabular}

Source: UN 1988. 
* The fossil and semifossil waters contained in the sediments of the continental shield, are often of marginal water quality. In fact, wells tapping these aquifers are preferred by pastoralists for the salt they provide their livestock.

* Groundwater associated with "sand" rivers is generally of very high quality and can be assumed appropriate for irrigation development.

Due to the small amount of industrial activity in West Africa, it is generally safe to assume that groundwater quality has not been degraded by industrial pollutants. Agricultural chemicals are also used sparingly in the region and as such pose no real threat to irrigated agriculture. Only in the vicinity of urban centers might fecal contamination be a problem.

\subsection{Agriculture}

The most important irrigated crop in West Africa is rice followed by other cereal crops. Other commonly irrigated crops are maize and vegetables. Wheat is sometimes irrigated in northern Nigeria. Millet and sorghum are important rain-fed crops. Table 7 shows the irrigated areas planted in different crop categories. Together, rice and other cereal crops accounted for 87 percent of the total irrigated land use in selected West African countries during the mid-1980s. Table 8 displays data on yields of selected crops in the region. It shows a consistent improvement in yield for rice from flood-recession or bottom land irrigation to irrigation under partial control (supply) and finally to irrigation under full control (supply and distribution). The yields for rice are reported to exceed an impressive 4 tons/ha for full control irrigation in most of the countries. The last column in Table 4 indicates average cropping intensity data for selected countries in West Africa. The cropping intensity figures are relative to estimated maximum potential, which in some cases is one crop and in others two crops per year. The overall average for the region is about 60 percent achievement of cropping intensity potential. Niger has the highest performance, with 80 percent achievement and Mauritania has the lowest achievement of potential, with 40 percent.

Another data set which provides insight into the relative importance of various irrigated crops in the region was developed by the FAO (1986a). As part of an inventory of existing irrigation systems, surface areas planted to various crops were tabulated. These data were not inclusive for any country but they reinforce the emerging picture of a cropping pattern revealed in Table 7 . The inventoried surface areas are:

* Burkina Faso, sugar 3,900 ha, vegetable 2,925 ha, rice 1,875 ha;

* Mali, rice 117,450 ha, sugar 20,500 , wheat 9,000 ha, vegetables 8,860 ha, cotton 2,350 ha;

* Mauritania, rice 21,650 ha, coarse grains 1,250 ha;

* Niger, vegetables 4,850 ha, coarse grains 3,739 ha, rice 3,620 ha, cotton 985 ha;

* Nigeria, vegetables 490,000 ha, coarse grains 415,000 ha, rice 5,300 ha; and

* Senegal, rice 93,450 ha, sugar 5,000 ha, vegetables 1,550 ha. 
Table 7. Crop areas as percent of total irrigated agricultural land and agricultural use of irrigated lands in selected West African countries.

\begin{tabular}{|c|c|c|c|c|c|c|c|}
\hline Country & Rice & $\begin{array}{l}\text { Other } \\
\text { cereals }\end{array}$ & $\begin{array}{l}\text { Market } \\
\text { garden } \\
\text { crops }\end{array}$ & $\begin{array}{l}\text { Fruit } \\
\text { crops }\end{array}$ & $\begin{array}{l}\text { Sugar- } \\
\text { cane }\end{array}$ & $\begin{array}{l}\text { Indus- } \\
\text { trial } \\
\text { crops }\end{array}$ & $\begin{array}{c}\text { Total } \\
(100 \%)\end{array}$ \\
\hline $\begin{array}{l}\text { Burkina } \\
\text { Faso }\end{array}$ & 65 & 3 & 13 & 1 & 18 & - & 100 \\
\hline Chad & 16 & 78 & 2 & - & 3 & 1 & 100 \\
\hline Gambia & 97 & - & 3 & - & - & - & 100 \\
\hline Mali & 82 & 16 & 0.5 & - & 1.5 & n.s. & 100 \\
\hline Mauritania & 24 & 72 & 4 & - & - & - & 100 \\
\hline Niger & 30 & 33 & 31 & - & - & 2 & 100 \\
\hline Senegal & 41 & 46 & 6 & - & 5 & 2 & 100 \\
\hline
\end{tabular}

Source: Violet et.al. (Data for 1986-89).

The diversity of irrigated crops reflects the diverse notch which irrigation fills across the region. The production of coarse grains is generally intended either as a hedge against future rain-fed crop failures or as an attempt to fill familiar nutritional requirements following a poor rain-fed harvest. Vegetables are almost exclusively grown for fresh marketing. With the notable exception of a Nigerian tomato paste industry, very little processing of these products takes place. They are generally viewed as a cash crop and are produced and marketed privately. Most rice, and almost all cotton and sugarcane are grown as part of government-sponsored agro-industrial initiatives. Production of these cash crops is often stimulated through government-sponsored subsidies and credit arrangements. Farmers often view them as a way to supplement income when they lack capital, atthough they often resent the stipulations placed on production by the agro-industrial enterprises. 


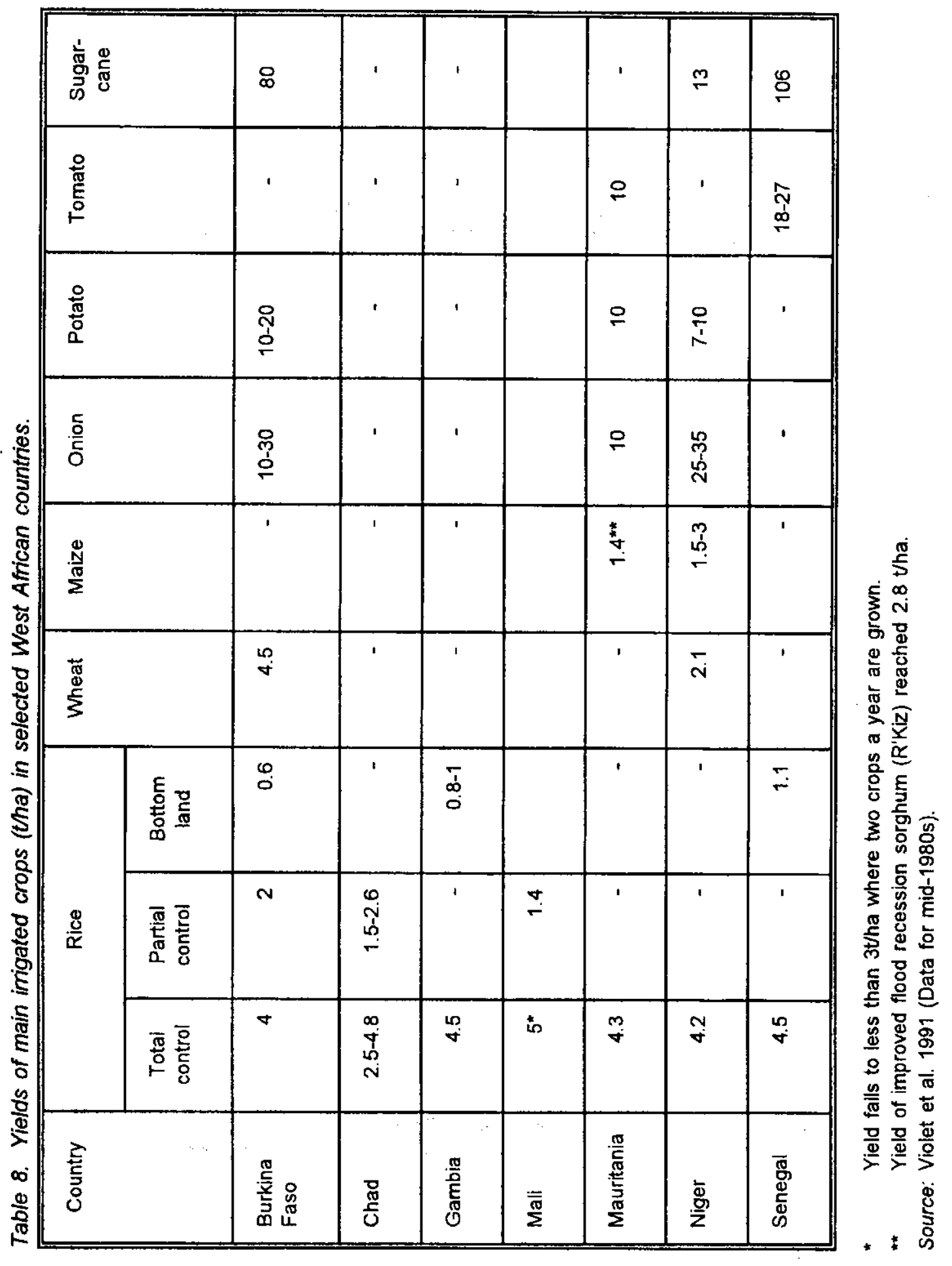




\subsection{Social Context}

The people of the Sahara are largely nomadic. Those who are sedentary live in communities built around oases which thrive mainly on commerce. At some of these oases, such as Faya Largeau in Chad or Bilma in Niger, the volume of water coming from springs permits the development of irrigated agriculture, primarily for dates. These systems are, however, limited in their current extent and their potential for expansion. In addition, they are largely gravity systems and as such as are outside of the purview of this report.

The inhabitants of the coastal regions are mainly sedentary farmers, but their production systems are primarily rain-fed. The principle culture is cassava which is not necessarily an irrigated crop. In addition, food gathering is practiced. What irrigation does exist, is oriented towards the production of market vegetables. Although these irrigation systems are commonly lift systems, the scale of the activity and its importance relative to other agricultural activities are minor.

The French were the main colonial power in the Sahel between the inlet of the Senegal River and the Lake Chad Basin. As a result, Chad has much in common with its francophone Sahelian neighbors to the west and is a member (along with Niger, Burkina Faso, Mali, Mauritania, Senegal, The Gambia, Guinea Bissau, and Cape Verde) of the Permanent Inter-State Committee for Drought Control in the Sahel (CILSS). Although it lies to the east of the line defining West Africa, Chad will be included in this study, partly because of the importance of the Lake Chad Basin in the region.

The per capita GNP in the region is about the lowest in the world. In 1987, it was at or below FCFA 70,000 (US $\$ 200$ ) per year in Burkina Faso, Chad, Mali and Gambiar while Niger had a 1987 annual per capita GNP of about FCFA 91,000 (nearly US $\$ 300$ ) and the corresponding figure for Mauritania was about FCFA 151,000 (US $\$ 400$ ), partly because of mineral resources. In 1987, 87 percent of the population of these Sahelian countries depended almost entirely on agriculture for their livelihood.

\section{Evolution of Lift Irrigation in West Africa}

\subsection{Importance of Lift Irrigation}

It is difficult to know exactly how lift irrigation in West Africa is developing relative to large-scale gravity systems, except that there are indications that it is developing faster than surface diversion systems. Most available data on irrigated surface areas do not distinguish between the two types of systems, nor do they offer a great deal of insight on how these surface areas have changed over time. Nonetheless, Table 2 contains some evidence to document this evolution in selected Sahelian countries (Violet et al. 1991). The data, particularly on the private systems side, must be viewed cautiously. Still, the increases are large enough to confidently assume that private systems, most of which are lift systems, are becoming increasingly important.

Circumstantial evidence to support this conclusion is readily available. The World Bank is expected to soon fund a Private Irrigation Development Project in Niger, which is designed to stimulate the development and use of tubewell/motor pump lift irrigation systems. In Chad, USAID is financing several small-scale groundwater irrigation projects and has phased out financing of the one gravity-fed system it had been supporting. Even in Nigeria, a country where significant investment continues in large-scale systems, it is recognized that quicker results (compared with large-scale systems), in terms of increased production, are obtained through promoting the small pumpset technology that produce fewer social problems (FAO 1991). 
This evolution is undoubtedly accelerated by the relative cost of developing small-scale lift irrigation versus large-scale schemes. A significant cost difference has been recognized for some time. Twenty years ago, des Bouvrie (1973) noted that the development of groundwater for irrigation is financially competitive with irrigation relying on full control of surface water. At that time, he quoted per hectare development costs of US\$55-US\$230 for groundwater irrigation and from US\$400 to US\$2,500 for surface diversion irrigation. He pleaded that groundwater irrigation should thus receive more attention for development.

More recent analysis reconfirms these earlier findings. Violet et al. (1991) produced the following cost estimates for various types of irrigation in the Sahel.

* Agency directed large-scale pump systems (US $\$ 20,000-$ US $\$ 32,000 / h a)$;

* Agency directed large-scale gravity systems (US\$6,667-US\$10,667/ha);

* Village-based pump irrigation systems (US $\$ 4,000-U \$ \$ 8,000 / \mathrm{ha}$ );

* Private groundwater irrigation systems (US\$800-US\$1,600/ha); and

* Improved traditional irrigation systems (<US\$800/ha).

Given the increasing demands on shrinking, or at best nonexpanding, development funds, and the historically poor performance of large-scale irrigation systems in West Africa, it is easy to see the rationale for the shift in priorities towards life irrigation.

\subsection{Traditional and Modern Lift Irrigation Technologies}

Both groundwater and surface lift irrigation systems in West Africa rely on the same battery of technologies to lift irrigation water from source to field. This section presents the most common of these technologies in a general context. Their specific application to pumping either groundwater or surface water will be discussed in Sections 5 and 6 .

Water lifting technologies employed in West Africa cover a wide range of technical sophistication. The degree of sophistication influences the cost of the technology as well as the volume of water available for irrigation. The following discussion presents the salient features of water lifting technologies used for lift irrigation in West Africa, beginning with the least sophisticated. Figures 2-5 are drawings of some of these technologies. Other, less common, pumps are not discussed. Work by the Institut Technologiuq DELLO (1991a and 1991b) was used in developing this section of the report.

Rope and bucket arrangements. Rope-and-bucket or rope-and-bag techniques are the simplest, and most common water-lifting systems in West Africa. The most simple are receptacles, tied on the ends of ropes, raised and lowered by hand to draw water from wells (Figure 4). In some systems, pulleys and other simple machines are employed to increase the efficiency of water lifting. Receptacles used in ropeand-bucket arrangements include hollowed out half gourds, leather and rubber bladders and plastic and steel buckets. Discharges provided by rope-and-bucket arrangements vary as a function of the volume of the receptacle and the distance over which it must be lifted. The cost of the technology is minimal, generally not exceeding US $\$ 10$ for the recipient and some locally manufactured rope. 
Figure 2. The "shaduf" counterpoise lift, West Africa.

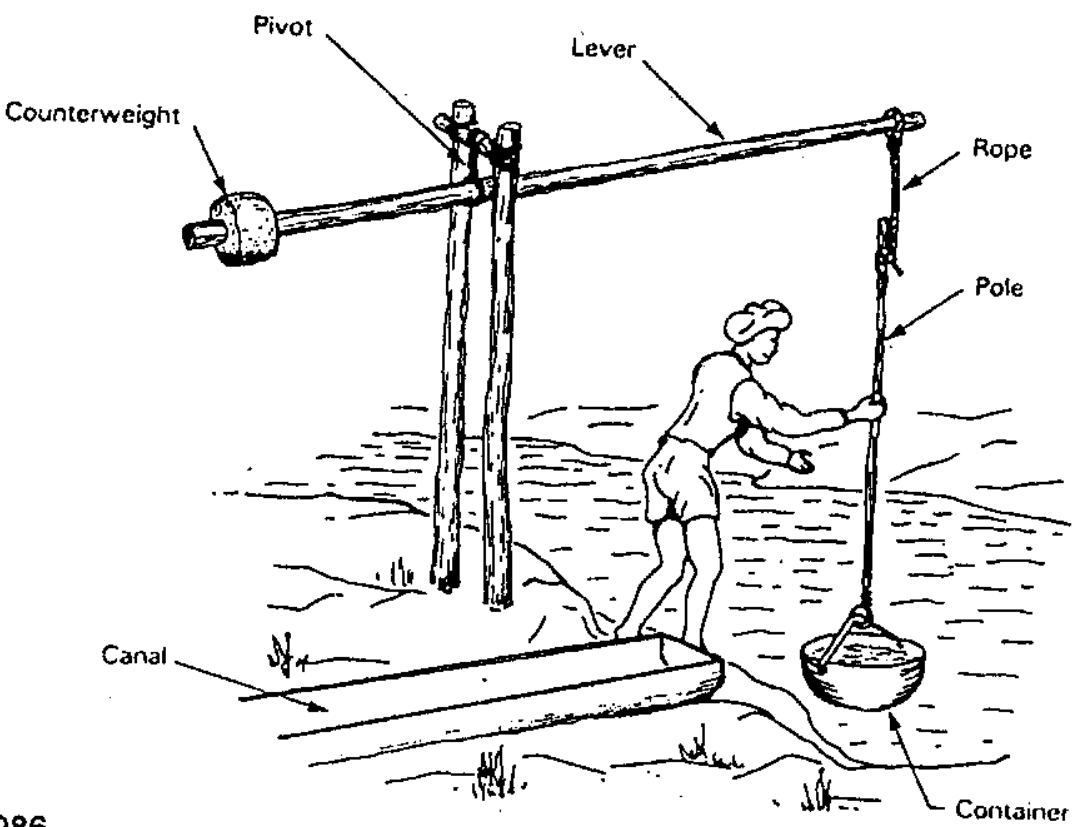

Source: FAO 1986.

Figure 3. Shaduf lifting water out of stream, Northern Nigeria.

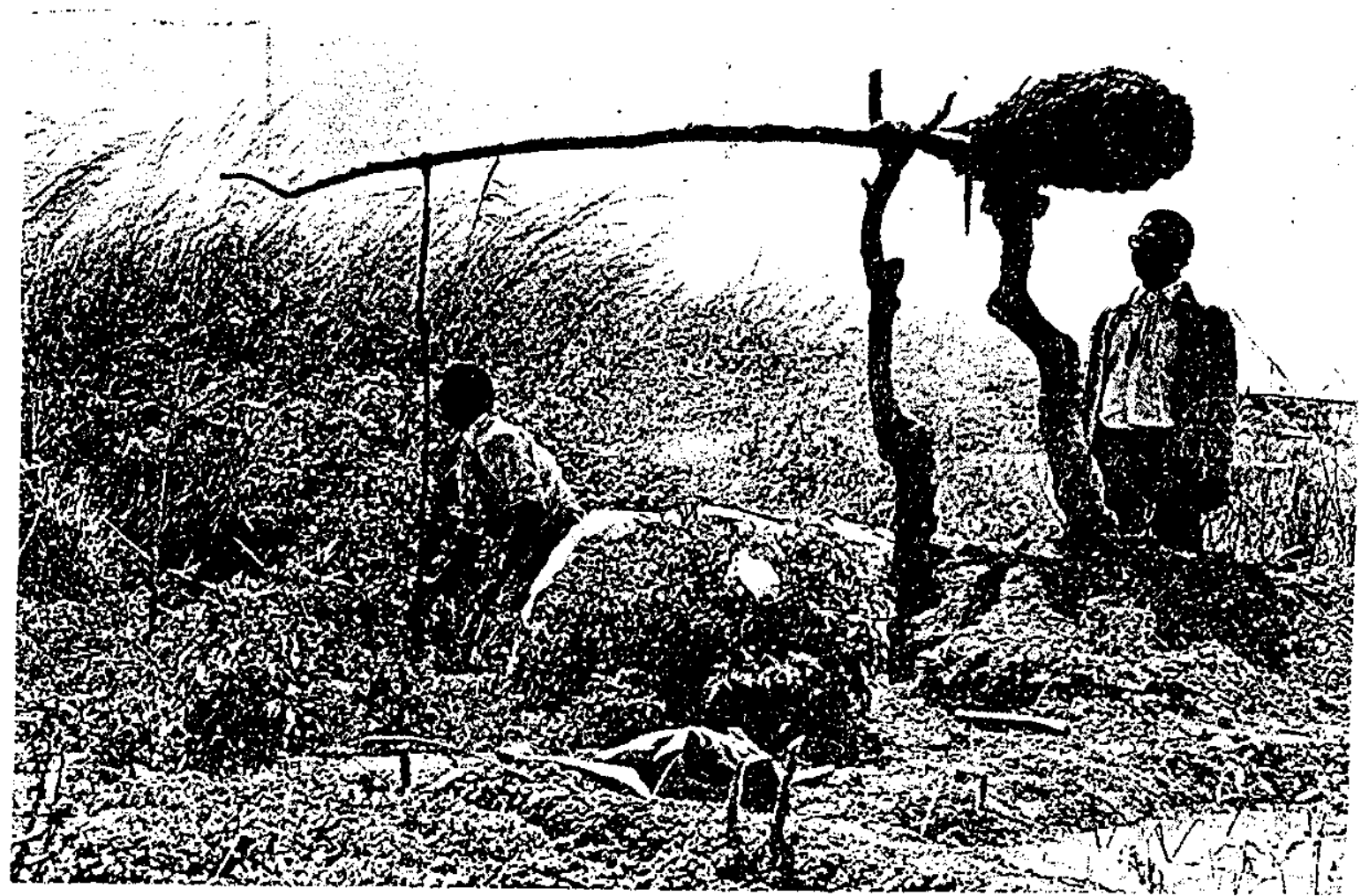

Source: Samaru 1981. 
Figure 4. Using rope-and-bag to lift water from a dug-well, West Africa.

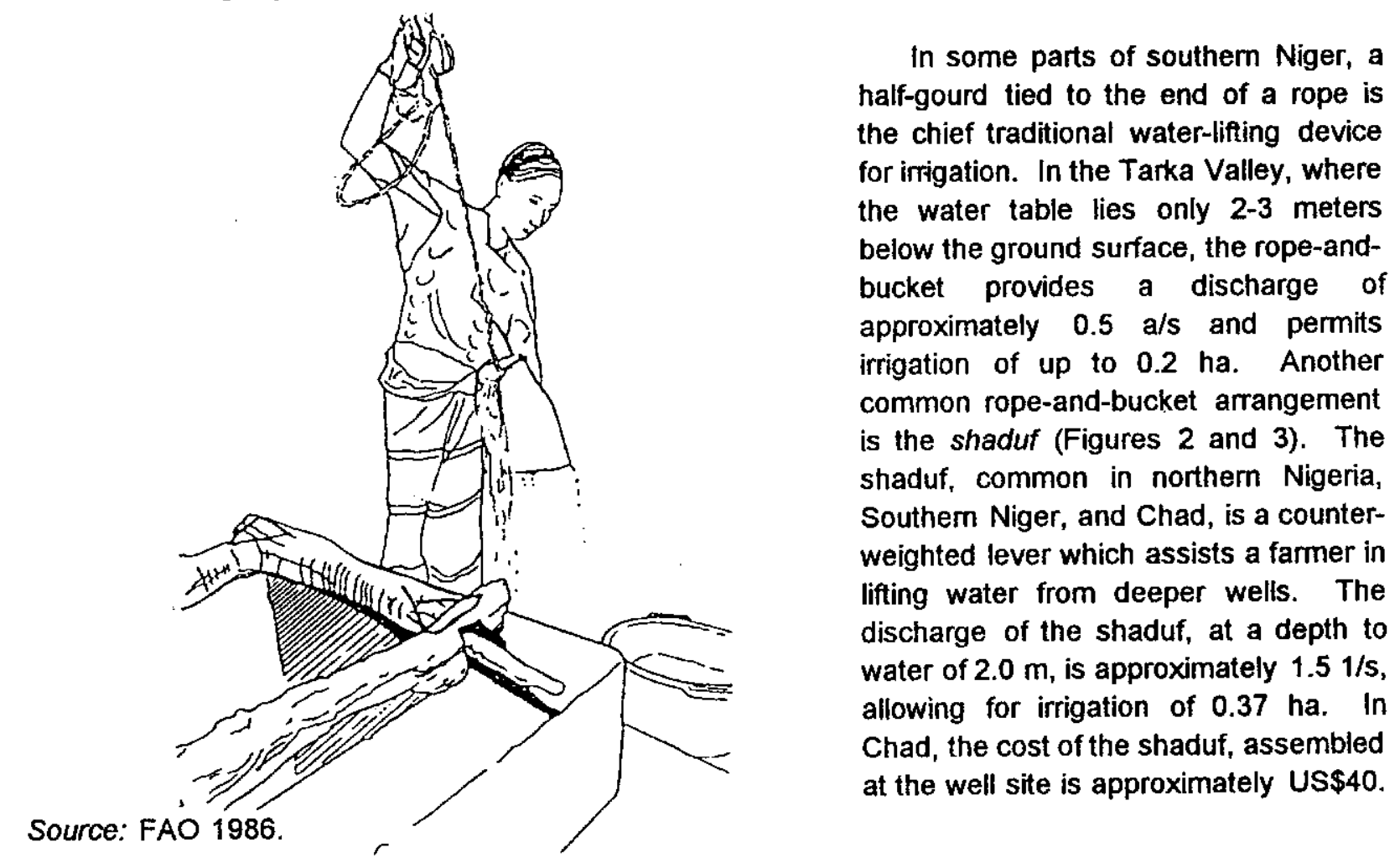

Figure 5. Portable axial flow pump, example of one type of surface lift irrigation technology.

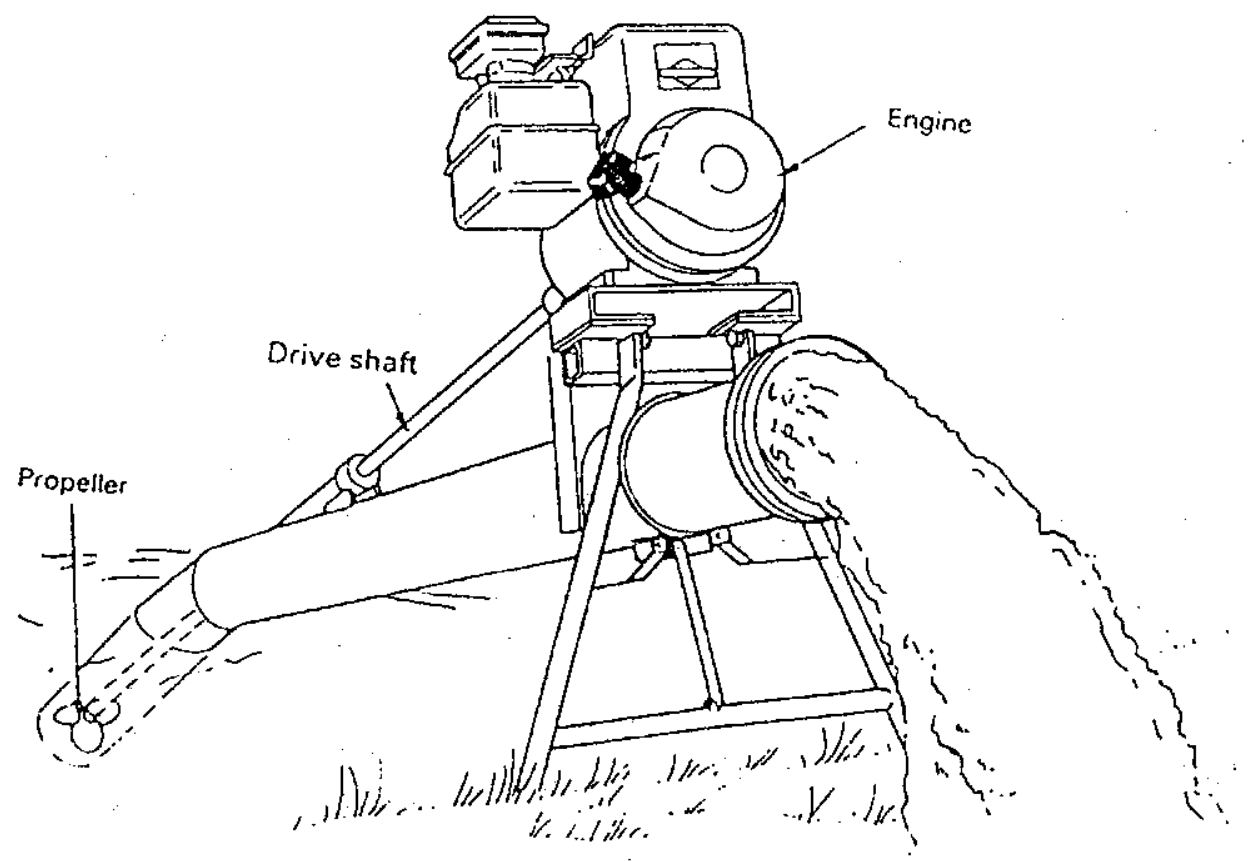

Source: FAO 1986. 
Manual devices. Manual water-lifting devices, commonly used for domestic water supply, are occasionally used for irrigation. In fact, many attempts have been made in West Africa to introduce manual water-lifting devices as an appropriate technology for irrigation. Unfortunately, recent experience reveals that they are generally more expensive than rope-and-bucket arrangements without providing significantly greater discharges. This limits their usefulness for irrigation. The most common manual device used for irrigation is the Burkinabe pump. This suction piston pump, which uses a locally crafted leather suction cup, can be installed either on a hand-dug well, a tubewell, or an open water source, although in most cases the water source does not generally effect the yield. At a depth to water of 2.0 $\mathrm{m}$, the pump had an approximate yield of $1.21 / \mathrm{s}$ and allowed for irrigation of $0.3 \mathrm{ha}$.

The rower pump and treadle pump are modifications on the Burkinabe pump which allow for the use of different major muscle groups during water lifting. Although they do provide greater discharges, approximately 1.5 and $2.01 / \mathrm{s}$ respectively, they are more costly to purchase and complicated to install and maintain. Mechanical problems, and the cost of resolving them, are thus of greater concern. In Chad, little interest in these pumps was expressed after a period of field testing.

The rope-and-washer pump is a positive displacement pump which offers a higher instantaneous discharge than either the rope-and-bucket arrangement or the Burkinabe style pumps. At $2.0 \mathrm{~m}$ depth the pump yields approximately $1.8 \mathrm{1} / \mathrm{s}$ and can irrigate up to $0.43 \mathrm{ha}$. The technology is very simple for farmers to understand and thus repairs are not problematic. Operation of the rope-and-washer pump is very tiring, however, and thus in the long-term, the time average discharge is not significantly greater than to devices previously mentioned. Farmers usually have a very good initial reaction to the pump, followed by a period of disillusionment.

The diaphragm pump is another pump which is impressive to farmers early on but which soon looses its luster. The attraction in the case of a diaphragm pump is the ease of operation resulting from its design. There is very little friction in the system and thus it is not tiring to operate. Unfortunately, the discharge yielded by the pump, approximately $1.51 / \mathrm{s}$ at a lift of $2.0 \mathrm{~m}$, is not significantly better than rope-and-bucket arrangements and thus the higher cost becomes a serious drawback.

Animal traction devices. Using the power provided by draft animals for water lifting is an attractive alternative in areas where there is a tradition of using animal traction. The nuances of using an animal for power, particularly related to the harnesses employed and the care and maintenance of the animal, make it somewhat difficult for the inexperienced to profit from animal traction. Those who have used animal traction for land preparation and transport, however, have been able to adapt their experience to water lifting.

The delou is a traditional animal traction water lifting device which has been perfected in Niger. This device employs a self-emptying leather bladder which is pulled from the well by an animal walking back and forth along a path leading away from the well. The technology yields approximately $2.01 / \mathrm{s}$ at 2.0 $m$ of lift, although the technology is particularly well suited for conditions where the depth to water limits the usefulness of manual pumps. The delou has been updated using more modem materials and is called the bidon verseur (pouring bucket). This device costs significantly more than the simple delou but it also yields a greater discharge. The flow pump, a rope-and-washer pump adapted for animal traction overcomes the tiring nature of operating this pump manually and offers a discharge of approximately 2.5 $1 / \mathrm{s}$ at a $2.0 \mathrm{~m}$ lift. In shallow water-table conditions, the Persian wheel or naria yields impressive discharges, $1.51 / \mathrm{s}$, and has proven very reliable. A secondary advantage of an animal traction waterlifting device is that the animal can be trained to be led by a child. This frees the farmer from the task of water lifting and allows him to concentrate on other agricultural practices or activities. 
Internal combustion pumps. There are two main power sources for internal combustion engines; gasoline and diesel fuel. Generally, gasoline-powered pumps are cheaper to purchase but are more expensive to operate (due to higher fuel costs and more frequent repairs) than diesel pumps. A brief description of gasoline and diesel-powered pumps used for lift irrigation in West Africa is presented below.

In recent years, gasoline-powered motor pumps have driven irrigation development in West Africa. Following the discovery of oil in Nigeria the gasoline-powered motor pump became increasingly common. These pumps, generally imported from the Far East, could be purchased for a reasonable price. In addition, the fuel costs were low due to government subsidies, spare parts were commonly available, and repair services initially set up for mopeds and motorcycles could easily branch into motor pump repair. Since the discovery of oil, roughly $300,000-500,000$ ha have come under irrigation from small motor pumps in Nigeria (Figure 5).

In countries neighboring Nigeria, the impact of the technology has also been strongly felt. In southern Niger, and northern Chad and Cameroon, small gasoline-powered motor pumps are becoming increasingly common. A favorable exchange rate between the CFA franc and the Nigerian Niara has led to a thriving black market in pumps, parts and fuel, making the technology very affordable. In these countries, a 3.5 horsepower (hp) motor pump can be purchased for the equivalent of US $\$ 300-U S \$ 800$. A pump of this size can provide a maximum discharge of approximately $7.01 / \mathrm{s}$ although the optimal discharge is closer to 4-5 $1 / \mathrm{s}$. This discharge should, in theory, permit the irrigation of up to 1 ha, although in practice other constraints (i.e., land preparation) usually prevent the achievement of this target.

In countries which do not directly border Nigeria, small gasoline-powered motor pumps become less affordable. In Burkina Faso, the average purchase price for a motor pump is US $\$ 160 / \mathrm{hp}$ while in Niger the cost is only US\$80/hp (Gay 1992). Fuel costs also rise in countries which do not border Nigeria, rising from US\$0.30/1 in Niger to US\$0.90/1 in Burkina Faso. These higher costs make small motor pumps less attractive as a water-lifting technology for irrigation.

Diesel pumps are generally larger than those powered by gasoline. The initial investment cost is, quite logically, higher as well. A $9 \mathrm{hp}$ diesel pump will cost upwards of the equivalent of US $\$ 4000.00$ if purchased in the region. A pump of this size can yield up to $41.71 / \mathrm{s}$ at shallow depths. This discharge far exceeds the yield capacity of most groundwater development technologies as well as the water required for the typical single landholding in West Africa. As such, diesel pumps are more suited to the development of irrigated areas containing multiple landholdings which rely on a surface body as a water source.

A summary of important parameters for some of the water-lifting devices described above are presented in Table 9.

The performance of manual water-lifting devices will depend on the physical constitution of the operator and may therefore be quite variable.

Alternative pumps. Two alternative energy sources have been applied to water lifting for irrigation in West Africa: solar power and wind power. The use of both these energy sources remains in a trial phase, neither currently being an important resource for lift irrigation in the region. The water-lifting technologies developed to harness these alternative energy sources do have, however, potential under specific conditions. In general, however, they require high levels of institutional development and a longterm planning horizon by farmers. 
Table 9. Physical characteristics of selected water-lifting devices.

\begin{tabular}{|c|c|c|c|}
\hline Device & $\begin{array}{l}\text { Head range } \\
(m)\end{array}$ & $\begin{array}{l}\text { Input power } \\
(\mathrm{kw})\end{array}$ & $\begin{array}{l}\text { Flow rate } \\
\left(\mathrm{m}^{3} / \mathrm{hr}\right)\end{array}$ \\
\hline Watering can & $3-5$ & 0.02 & 0.5 \\
\hline Shadouf & $1-3$ & $0.02-0.08$ & $2-4$ \\
\hline Dalou & $5-10$ & $0.5-0.6$ & $5-15$ \\
\hline Rope and washer & $5-20$ & $0.02-1.0$ & $5-30$ \\
\hline Diaphragm & $1-2$ & $0.03-5.0$ & $2-20$ \\
\hline Piston & 5 & 0.03 & 2 \\
\hline Rower & - & - & 1.75 \\
\hline Centrifugal & $5-60$ & $0.4-500$ & $1-50$ \\
\hline
\end{tabular}

Source: FAO 1986b.

Electric pumps driven by solar energy using photovoltaic cells require a large initial investment of up to US\$26,000. This far exceeds the capital available to individual farmers, and most rural communities in West Africa. This requires the creation of credit arrangements. Once the system has been installed, however, the cost of operation is minimal. A typical solar pump has a discharge of $50 \mathrm{~m}^{3} /$ day (a time averaged discharge of $0.61 / \mathrm{s}$ ). In order to take full advantage of this volume of water, either storage capacity is required to collect the water pumped at night, or irrigation must take place 24 hours per day. The first option requires additional investment to develop a storage capacity, the second, institutional arrangements to organize the irrigation rotation. The cost of the technology requires that the farmers possess a long-term commitment to irrigated agriculture and are willing to irrigate year-round.

Windmills have also been tested for irrigation in West Africa. This technology can only be employed in regions with adequate wind resources. In general, 6-8 hours/day of wind, with an average velocity of at least $4 \mathrm{~m} / \mathrm{s}$, are required. These conditions are generally found from the Atlantic coast of Senegal across the Sahel to Chad. Two types of windmills have been employed, the first linking the windmill mechanically to a piston pump such as the Burkinabe. These can cost upwards of US $\$ 1,000$ to install and their discharge is limited by the potential discharge of the pump. The second type employs a windmill to generate electricity which drives a submersible pump. This type of windmill yields a significantly higher discharge, up to $15 \mathrm{l} / \mathrm{s}$, but is also more costly, running around US $\$ 20,000$ installed, 
and can only be justified if $\mathbf{2 4}$ hour irrigation or night water collection and storage are practiced. The discharge provided by windmill pumps is highly dependent on the depth to water and the wind resource.

\section{Groundwater Lift Irrigation in West Africa}

\subsection{Local Technologies for Groundwater Development}

Groundwater development technologies in West Africa range in sophistication from technologies which have been locally mastered for generations to those which have been introduced more recently. The depth at which groundwater can be developed, the types of formations which can be traversed, and the potential well yield are all related to the type of groundwater development technology employed. The degree of sophistication also influences the cost of the technology. The following description of groundwater development technologies begins with the least sophisticated.

Hand-dug wells. Hand-dug wells, as their name implies, are wells constructed using hand tools. Generally, traditional well-diggers develop the well by physically descending into the well and sending cuttings to the surface via rope-and-bucket arrangements. The diameter of hand-dug wells is generally greater than 1 meter to allow enough work space for the well-digger. These groundwater development structures are the most common in the region, being used for water supply as well as for irrigation. They are most appropriate for aquifers contained in weathered and fractured crystalline basement rock and alluvial deposits where digging with hand tools is possible. Depending on the depth to the water table, hand-dug wells can be as shallow as a couple of meters and a deep as 20 or 25 meters.

Traditional hand-dug wells are either unlined or lined with some locally available material. Branches are generally used to line hand-dug wells in cases where the sides of the well are not stable. Unfortunately, this puts added pressure on dwindling forest resources in many parts of West Africa, putting in doubt the long-term sustainability of this traditional well-lining technique. For hand-dug wells, the rate of advance is dependent on geologic formations being traversed and the depth from which cuttings must be lifted. In compacted clay, however, a skilled well-digger can dig an unlined $6 \mathrm{~m}$ well in a couple a days. Lining with branches adds about one day to the process. Traditional hand-dug wells have the major disadvantage that they generally tap only $0.5-1.0 \mathrm{~m}$ of aquifer, limiting the well-storage volume and well-recharge rate to the point that the well cannot support certain water extraction technologies. The cost of a $6 \mathrm{~m}$ deep unlined hand-dug well is approximately US\$40.00. If the well is lined with branches, the cost can be as high as US\$120.

In cases where the well walls are not stable enough to support themselves during digging, an improved well lining method is often employed. This is particularly important when the aquifer being tapped is fluid and has a tendency to fill the space created by digging. Three well-lining methods commonly employed in West Africa are: lining with steel barrels, lining with cement bricks, and lining with steel-reinforced concrete.

Barrel linings are easily crafted from old 55-gallon drums at a cost of approximately US\$8 per linear meter over and above the cost of digging an unlined well. The barrel well-lining cylinders can be introduced at the surface and lowered during well digging, permitting the use of hand-dug wells in unstable formations. Barrel linings have no structural continuity, however, and they can corrode and deform quite easily in mobile water bearing units. Cement brick well columns are stronger, their shape discouraging deformation. It is also possible to structurally link one course of bricks to the next. At US\$25 per linear meter the method is attractive for individual irrigation development. Unless the bricks are perfectly shaped, however, gaps in the well lining are common and can lead to the silting up of the 
capturing column. Steel-reinforced wells are the most structurally robust. They aliow for significant capturing depths which increase the well storage capacity and recharge rate. At US\$300 per linear meter, their cost can be considered prohibitive to irrigation development by individuals.

Tubewe/ls. In many cases hand-dug wells are not appropriate for local conditions because they are either difficult to install or unable to provide the water required for irrigation. In these cases, tubewells are a more appropriate technology for groundwater development. Tubewells, small-diameter pipe columns linking the ground surface with underlying aquifers, tap the water resource via either a terminal opening or a slotted well screen. Several methods exist for installing tubewells, the appropriate method being a function of the target tubewell depth, the formations which must be traversed, and the required well yield. Four tubewell installation methods, common in West Africa, are described below. The first three are appropriate for aquifers contained in weathered basement rock and alluvium. The last method is applicable to nearly any aquifer type.

The simplest tubewell installation methodology is the use of a hand-auger. The method, perfected by Luthern World Relief in Niger, relies on a simple auger which can be fabricated by local blacksmiths. The auger is operated by two individuals who advance it by atternatively turning the auger and pulling it back to withdraw the cuttings. Once the desired depth has been achieved, a PVC plastic well, with a locally crafted slotted screen, is installed in the hole. The well is protected from the intrusion of fine sand by a nylon mesh and is outfitted with a simple bailer. The cost of materials alone is US\$15 per linear meter and the well yield is between 0.5 and $1.01 / \mathrm{s}$.

A second tubewell installation method is the washbore approach commonly used in northern Nigeria (Carter 1992). This method requires the availability of a motor pump and a separate source of water and results in the direct installation of the permanent well into the aquifer. A PVC pipe column is generally installed by pumping water through the pipe string. The jet of water emerging from the end of the string serves as a cutting tool which loosens the earth and allows for the lowering of the well. Tubewells installed by the washbore method usually have a single terminal opening although a few have well screens. These wells can generally be installed to an approximate depth of $10 \mathrm{~m}$ at a subsidized cost of US\$2 per linear meter in Nigeria and can yield up to 3 or $41 / \mathrm{s}$.

The "sludger" method is another manual tubewell installation technique. It relies on a recirculating drilling fluid, commonly water laden with clay. A hollow galvanized pipe string, equipped with a sharpened cutting tool on the end, is manipulated in short vertical motions with the help of a lever. A hand placed over the top of the pipe string serves as a valve. On the down stroke, the hand is open and drilling fluid is expelled from the string. Cuttings are entrained in the drilling fluid when the drill string hits the bottom of the borehole. These cuttings are lifted from the well as the pipe string is pulled back with the hand closed. In this way the drill string is advanced to the desired depth. Once this point has been reached, the drill string is retracted and a PVC tubewell with a locally crafted slotted well screen is introduced. A developed gravel pack is installed to prevent the intrusion of fines. Flow rates of over 7 $1 / \mathrm{s}$ have been obtained in West Africa using this method, at a cost of US $\$ 30.00$ per linear meter.

The final method of tubewell installation involves the use of drill rigs. Drill rigs employ a variety of drilling methods depending on the local conditions. Driscoll (1986) describes in detail various well-drilling techniques. In West Africa, the two most common methods are percussion and rotary methods, although it must be pointed out that in rural areas drill rigs are rare. In general, drill rigs are used in regions where the installation of water-supply tubewells is necessary due to the types of aquifer present. The cost of drilling can exceed US $\$ 200$ per linear meter, well beyond the means of a farmer hoping to develop a personal water source for irrigation. 